\title{
Reframing Arctic governance and the Asian states
}

\author{
S. G. Sreejith ${ }^{1} \cdot$ Kamrul Hossain ${ }^{2}$
}

Published online: 11 April 2017

(C) O.P. Jindal Global University (JGU) 2017

\section{Introduction: introducing the idea of the Arctic}

The Arctic, albeit an esoteric region enclosed by eight circumpolar states, is considered as a "global space" located beyond national jurisdictions. The Arctic is called a global space because it engenders intersubjective political interests across the states of the world and causes interstate relations to converge on the region. This global space, among other imaginations and possibilities, is primarily a maritime area of the Arctic Ocean. As far as the legal status of the region is concerned, there is hardly a state in the international community of states which has not acknowledged the legal status of this particular geographical area as it is demarcated and codified under international law.

The Arctic as a whole has a unique biogeographic status because of its distinct ecosystem which is a life support to thousands of living organisms including a large number of charismatic marine mammals. Further, the presence of sea ice and the pristine environmental characteristics as well as the rich terrestrial and marine biodiversity make the Arctic distinct when compared to other regions of the globe. It is thus often argued that the Arctic is a Common Heritage of Mankind which should

S. G. Sreejith-Associate Professor, Associate Dean (Academic Affairs), and Executive Director; Kamrul Hossain-Associate Professor and Director.

S. G. Sreejith

sgsreejith@jgu.edu.in

1 Centre for International Legal Studies, Jindal Global Law School, O.P. Jindal Global University, Sonipat, India

2 Northern Institute for Environmental and Minority Law, Arctic Centre, University of Lapland, Rovaniemi, Finland 
be sustainably explored and preserved. ${ }^{1}$ Thanks to the aforesaid specialness the Arctic demands a protection-regime in which not only the circumpolar Arctic states but also other states of the world are relevant actors.

Until recently, the Arctic as a region was not a priority for the Asian states; however, it may be the mysterious factuality of the pre-geopolitical introversion turning into a post-global extroversion, it has become a socio-political fact that since the end of the last decade there has been greater interest and involvement among the Asian nations in Arctic affairs. In 2013, the Kiruna Ministerial Meeting of the Arctic Council, the high level intergovernmental forum of the eight Arctic nations, endorsed a resolution admitting five Asian states-China, India, Japan, Singapore and South Korea-as observers in the Council. ${ }^{2}$ Even though the observer status in the Arctic Council does not get these states' involvement in decision-making processes, it is a clear indication of the growing interests of Asian states towards the Arctic region. ${ }^{3}$ This growing interest, if not a mounting concern, on the Arctic is arguably (keeping apart the above said twist of modernity) due to the increase in harmful human activities in the region, which has been gradually on the rise, resulting in global climate change and its associated effects. Moreover, the opportunities for the exploitation of the Arctic's rich natural resources, both living and non-living, as well as the seasonal use of the newly emerging Arctic sea routes, which are shorter and capable of saving time and energy, make the region salient in the geopolitical landscape.

The governance structure of the Arctic comprises partly of a fine mix of laws and regulations and mostly of resolutions made within regional bodies, the so-called soft law tools. The former are in the nature of international legal instruments, whereas the latter are regionally oriented instruments, which narrow the scope for non-Arctic states to have active involvement in Arctic affairs. Nevertheless, due to the transnational and transregional nature of global geopolitics, there has been a policy demand for a multi-level governance of the Arctic region.

\section{This special issue}

Since policy, law, and politics are poised in a complex relationship to each other apropos of the Arctic, the need to see through them and understand their interactive effect is important for an effective governance of the region by the Arctic states and for a meaningful participation in the Arctic governance by other states. It has therefore become pertinent to explore: how Arctic related challenges are addressed in a more inclusive manner. That is to say, whether the existing structure of governance needs to be strengthened/revised taking into account the stakes of non-

\footnotetext{
${ }^{1}$ See e.g. Neil Gadihoke, The Arctic: Geopolitics, International Relations, and Energy Security: A View from India, in, ENERGY SECURITY AND GEOPOLITICS IN THE ARCTIC: CHALLENGES AND OPPORTUNITIES IN THE 21ST CENTURY 180 (Hooman Peimani, ed., 2013).

${ }^{2}$ Kiruna Declaration, Arctic Council Secretariat, Kiruna, Sweden 15 May 2013, available at https:// oaarchive.arctic-council.org/bitstream/handle/11374/93/MM08_Final_Kiruna_declaration_w_signature. pdf? sequence $=1 \&$ isAllowed $=\mathrm{y}$.

${ }^{3}$ See Per Erik Solli, et al., Coming into the Cold: Asia's Arctic Interest, 36 (4) POLAR GEO. 253 (2013).
} 
Arctic states or whether the challenges are best addressed through multi-level forums, such as the UN, the EU as well as the Arctic Council where non-Arctic states are placed in different settings. Through this special issue of Jindal Global Law Review, primarily, we look for knowledge/information on the role of the Asian countries in Arctic governance: How Asian states perceive the Arctic region and the problems thereof? What implications Asian states [will] have as a result of the challenges within the Arctic? How do the emerging Asian nations play around the economic interests generated from the Arctic and the broader goal of maintaining sustainable development in the region? How do they perceive the so-called "Arctic exceptionalism" while looking for a governance model, and their position in such a model?

Addressing these question, we have an array of research by various scholars on the region. While these contributions offer the possibilities for various sequential imaginations, we have chosen to arrange them in the order that our readers get to know the institutional landscape, what we would prefer to called as the sites of Arctic cooperation, wherein Asian participation in the Arctic will occur. This is followed by contributions on Arctic policies of India and China, and the unified polices of North East Asian states and Asian-Arctic states. While our lead articles individually pose many interesting formulations, collectively they have been able to polemicize the Asian participation in the Arctic, setting future agendas of research in Arctic cooperation.

\section{Contributions}

The first article is by Kamrul Hossain and Marija Mihejeva, Governing the Arctic: Is the Arctic Council Going Global? In this piece the authors engage in an internal critique of the Arctic Council, which is the site of Arctic cooperation, wherein the interests of the Arctic and the non-Arctic states on the Arctic coalesce. Hossain and Mihejeva focus on the scope and structural sufficiency of the Arctic Council as an institution to accommodate the new observer states, meet their expectations, and provide them a meaningful participation in the work of the Council. Reviewing the structure of the Council, the authors argue that though the Council is committed to multilateralism and global participation, an Arctic exceptionalism has an imperceptible presence in the veins of the Council, which limits the internationalization of the work of the Council-the Arctic Council, argue Hossain and Mihejeva, is far from being global. Hossain and Mihejeva further argue for an "effective engagement" by the Arctic Council with the Observer states: "[T]he ongoing transformation of the Arctic, both geo-physically and geo-politically, demands broader inclusiveness" which will in turn enhance the legitimacy of the Arctic Council at large. As a project of reform, Hossain and Mihejeva propose to start with a recognition of the legitimate interests of the non-Arctic observer states which would help the Council create a climate of acceptance and openness.

The problematization of the structure and functions of the Arctic Council by Hossain and Mihejeva opens possibilities for reimagining the participation of the Asian states in Arctic affairs in general and in the Arctic Council in particular. The 
article draws attention to the need of a structural reform within the Council in order to effectuate the formula of effective engagement.

This mapping of the Arctic public spaces of democratic participation by Hossain and Mihejeva is followed by four studies which examine the look-Arctic policy of two Asian states-India and China-and of the North East Asian states and the Asian-Arctic states in general. P. Whitney Lackenbauer in his piece, India and the Arctic: Revisionist Aspirations, Arctic Realities surveys the many narratives New Delhi has on India's interest and possible participation in the Arctic. He observes that such narratives are diverse yet are polarized between the idealism of India's scientific curiosity about the Arctic and the realism of economic and strategic opportunities the region offers to India, creating the image of a "new Great Game" that is moving north. Lackenbauer also maps two narratives which stand outside the polarity of idealism-realism. First, the narrative of an "emerging Arctic saga where enhanced cooperation and coordination with the Arctic states ... can serve India's national and international interests". Second, a narrative that aims to make the Arctic a global commons so as to have India making a "'historic contribution' as a responsible global power", challenging the exclusivity and monopoly a few states have over the Arctic. According to Lackenbauer, what has prompted India to take a greater interest in the Arctic is a policy that has emerged out of a combination of the above said narratives. However, Lackenbauer lays down a set of considerations on the basis of which India may make a rational choice in terms of its Arctic participation.

The second paper that deals with a look-Arctic policy is by Nengye Liu, China's Emerging Arctic Policy: What are the Implications for Arctic Governance? Liu genealogically reverts to the Chinese interest in the Arctic in order to understand the possible Chinese participation in the region. Liu has taken this approach, for he, as he puts it, is less motivated by the academic and non-academic speculations on what is China's Arctic policy; rather he wants to understand the Chinese position on the Arctic on the basis of what does China want from the Arctic? Through his genealogical revert, Liu classifies the possible Arctic participation of China into three: First, the sharing by China of the normative commitment of the Arctic states towards the protection and betterment of the region (Mutual Respect); Second, to participate in and contribute to the transregional possibilities apropos of, e.g. science, shipping, environmental protection, and resource development, which the Arctic region offers (Cooperation); Third, reciprocal support to each other (Winwin) through research and business collaboration. On balance, Liu presents a counter case to the political myth that Chinese participation in the Arctic will be security-centered.

On this point, Giuseppe Amatulli's piece, The Role of China in the Arctic: Challenges and Opportunities for a Sustainable Development of the Region becomes an excellent afterthought on Liu's formulations. Amatulli's observations on China's Arctic policy more or less match with the observations of Liu. However, Amatulli identifies certain issues in the national framework of China which can substantially impede China's participation in the Arctic. Such issues primarily pertain to the Chinese approach to sustainable development and rights of indigenous peoples, areas wherein China is yet to develop robust legal and policy frameworks. 
Unless and until China addresses these issues, it cannot earn the confidence of the Arctic states about the committed participation which China is looking forward to in the region.

While we recognize the continuity Amatulli's piece provides to Liu's formulations, the papers need not be arranged necessarily in a sequential order. This is for two reasons: First, Liu's paper is a formulation of the Chinese policy on the Arctic as it is reflected through Chinese foreign policy and practice. In that perspective, there is a sufficiency in Liu's formulations-his paper fulfils the analytical promises it makes. Second, Amatulli's piece can be a standalone critique of the Chinese preparedness to participate in Arctic affairs. That is to say, rather than the information on the Chinese policy on the Arctic it provides, what makes the piece distinct is the problematization it has of China's oversight on the internal approaches to issues similar to that of the Arctic. Hence, we have situated Amatulli's paper as a short note in this special issue.

Yet another piece that provides details on the look-Arctic policy of the Asian states is by Viatcheslav Gavrilov and Alexandra Kripakova, Arctic Policy of the North East Asian Countries. This paper analyses the possible participation of three North East Asian (NEA) states_China, Japan, and South Korea—through a unified policy lens. Gavrilov and Kripakova unify the NEA states' Arctic policy through a historical analysis of the interests and participation of these states in Arctic affairs. Further, what may be called a NEA states' approach is developed taking into account the shared economic, demographic, and environmental features of the NEA states. Gavrilov and Kripakova explain the logic and utility of this analytical position succinctly: "Whereas the possibilities and extent of involvement of NEA states' implementation of Arctic projects are different, they are combined by a motive to justify their need while exploring the Arctic". This logic is foundationalized on the understanding that deep down the divergent interest of NEA states in the Arctic, there are certain basic motivations, e.g., economic advantages, which unify the Arctic interests of NEA states. Through this lens the authors provide a detailed analysis of the possible involvement of a unified front in Arctic affairs, though they hold reservations about the politicization of a unified participation in the Arctic.

The article by Marc Lanteigne, Walking the Walk: Science Diplomacy and Identity-Building in Asia-Arctic Relations is similarly placed as the piece by Gavrilov and Kripakova in terms of its approach. Interestingly, this piece advances a unified Asian approach towards the Arctic of, what Lanteigne calls, "the AsiaArctic Five" (AA5). The article captures the pre- and post-Kiruna challenges faced by the AA5, especially to convince the Arctic states and the global community that their interest in the Arctic transcends parochial economic interests and any free ride thereof. Lanteigne captures the Asian response to a general mistrust which permeated the Arctic circles about the participation of Asian states in Arctic affairs. He presents the strategy of "scientific diplomacy" adopted by the Asian states of enhancing scientific participation in the Arctic yet keeping an economic leitmotif in such endeavors. Within this unifying lens, Lanteigne situates the individual scientific endeavors of each Asian-Arctic state, showing their respective contribution to scientific diplomacy. While AA5 as a unified entity is yet to traverse the 
wetlands of policy and diplomacy, each individual state in the AA5 has some success in finding economic participation and earning economic benefits.

Interestingly, the concept of a unified Arctic policy for AA5 and NEA states well concludes the look-Arctic policy of Asian states. Having presented the Arctic ambitions of India caught between an idealism-realism binary and of China for a multilevel participation that goes beyond strategic interests, the unified approach has created critical imaginations regarding the politicization of the participation of Asian states in Arctic affairs. Whether the nature of the Arctic participation of the Asian states should be left to individual interest and policy choices of the respective Asian states or should there be a unified Asian approach to Arctic are polemical questions that this special issue opens for future research.

Finally, this special issue also presents a book review by Mia M. Bennett, Arctic Law and Governance: The Role of China and Finland (Timo Koivurova, Tianbao Qin, Tapio Nykänen, and Sebastien Duyck, eds., 2017). The review has critically appraised a collection of comparative studies conducted by various Finnish, Chinese, and European scholars on the Arctic polices of Finland and China and various levels of cooperation in the Arctic between the Arctic Finland and the nonArctic China.

\section{Conclusion}

The concept of this special issue was born out of the Finnish Academy project, HuSArctic, headed by Kamrul Hossain and the collaboration between us which the project facilitated. Hence we are thankful to the many collaborators of the project, some of them became our contributors. We are indebted to all our contributors who ensured that their contributions reflect the true spirit of our concept note. Had it not been for their cooperation we would not have been able to turn this special issue into an addition to the growing epistemology of the law relating to the Arctic. We sincerely hope that our effort in organizing these researches will persuade many researchers to focus on Asian interest and possible participation in the Arctic, engendering newer ideas and imaginations. Finally yet importantly, we extend our thanks to Jindal Global Law Review and everyone associated with it for hosting us and our thematic collection. ${ }^{4}$

We sincerely hope that our readers will enjoy this special issue!

\footnotetext{
${ }^{4}$ In this connection, we also extend our sincere thanks to Prof. C. Raj Kumar, Editor in Chief, Jindal Global Review (JGLR), Vishwas Devaiah, Managing Editor, JGLR, and editors of Springer who helped us in one way or another in the production of this issue.
} 